\title{
Low Frequency of Horizontal and Vertical Transmission of Cucurbit Leaf Crumple Virus in Whitefly Bemisia tabaci Gennadius
}

\author{
Kiran R. Gadhave,,${ }^{1,2, \dagger}$ Saurabh Gautam, ${ }^{1}$ Bhabesh Dutta, ${ }^{3}$ Tim Coolong, ${ }^{4}$ Scott Adkins, ${ }^{5}$ and Rajagopalbabu Srinivasan ${ }^{1}$ \\ ${ }^{1}$ Department of Entomology, University of Georgia, 1109 Experiment Street, Griffin, GA 30223, U.S.A. \\ 2 Department of Entomology and Plant Pathology, North Carolina State University, Raleigh, NC 27606, U.S.A. \\ ${ }^{3}$ Department of Plant Pathology, University of Georgia, 2360 Rainwater Road, Tifton, GA 31793, U.S.A. \\ ${ }^{4}$ Department of Horticulture, University of Georgia, Athens, GA 30602, U.S.A. \\ ${ }^{5}$ U.S. Department of Agriculture-Agricultural Research Service, U.S. Horticultural Research Laboratory, Fort Pierce, FL 34945, U.S.A. \\ Accepted for publication 23 February 2020.
}

\begin{abstract}
Cucurbit leaf crumple virus (CuLCrV), a bipartite begomovirus, is transmitted by whiteflies in a persistent and circulative manner. Like other begomoviruses, CuLCrV transmission via feeding is well understood; however, whether and how CuLCrV is transmitted by horizontal and vertical modes in its vector, Bemisia tabaci, remains unexplored. We studied transovarial and mating transmission of $\mathrm{CuLCrV}$, and comparatively analyzed virus accumulation in whiteflies through feeding and nonfeeding modes. Furthermore, we quantified CuLCrV DNA A accumulation at different time points to determine whether this virus propagates in whiteflies. $\mathrm{CuLCrV}$ DNA A was transmitted vertically and horizontally by $B$. tabaci, with low frequency in each case. Transovarial transmission of CuLCrV DNA A was only $3.93 \%$ in nymphs and $3.09 \%$ in adults. Similarly, only a single viruliferous male was able to transmit CuLCrV DNA A to its nonviruliferous female counterparts via mating. In contrast, viruliferous females were unable
\end{abstract}

ABSTRAC

The nonfeeding (i.e., transovarial and mating) modes of transmission and prospective roles in virus dispersal remain underexplored for the majority of plant viruses. Such transmission modes are relatively well studied in plant viruses that propagate in insect vectors as opposed to the ones that do not (Jia et al. 2018). For propagative plant viruses, these modes of transmission are likely to hold greater functional and evolutionary significance than the nonpropagative ones (Jia et al. 2018; Whitfield et al. 2015). Virus propagation in insect vectors appears to be a common feature for the majority of persistent propagative RNA viruses from the virus families Rhabdoviridae, Reoviridae, Phenuiviridae, and Tospoviridae (Hogenhout et al. 2008). For instance, the type species Tomato spotted wilt virus in the genus Orthotospovirus and family Tospoviridae is widely studied in the context of plant virus replication in its insect vector, Frankliniella occidentalis (Roselló et al. 1996). Unlike RNA viruses, begomoviruses, including tomato yellow leaf curl virus (TYLCV), are not known to replicate inside whiteflies (Bosco et al. 2004; Czosnek et al. 2002; Ghanim et al. 1998; Sánchez-Campos et al. 2016), except for contrary evidence by Pakkianathan et al. (2015) suggesting otherwise. Like RNA viruses, begomoviruses exhibit strong association with the vector Bemisia tabaci (Gennadius), with a variety of long-term effects on fecundity and longevity (Brown et al. 2012). These effects are reported to vary from being deleterious to neutral to beneficial.

†Corresponding author: K. R. Gadhave; krgadhave@ncsu.edu

Funding: The research was partially supported by the Georgia Commodity Commission of Vegetables.

The author(s) declare no conflict of interest.

(c) 2020 The American Phytopathological Society to transmit CuLCrV DNA A to nonviruliferous males. Additionally, the recipient adults that presumably acquired $\mathrm{CuLCrV}$ transovarially and via mating were not able to transmit the virus to squash plants. We further report that the CuLCrV DNA A viral copy numbers were significantly lower in nonfeeding modes of transmission than in feeding ones. The viral copy numbers significantly decreased at succeeding time points throughout adulthood, suggesting no $\mathrm{CuLCrV}$ propagation in B. tabaci. Altogether, the low frequency of nonfeeding transmission, reduced virus accumulation in whiteflies, and absence of plant infectivity through nonfeeding transmission suggest that transovarial and mating CuLCrV transmission might not substantially contribute to $\mathrm{CuLCrV}$ epidemics.

Keywords: biotype B (MEAM 1), ecology and epidemiology, mating transmission, replication, transovarial transmission, virology

In the absence of virus infection in primary host plants, the nonfeeding modes of transmission, together with the presence of alternate host plants, are likely to maintain virus inoculum in agroecosystems, to facilitate virus survival in adverse environmental conditions, and to enable virus spread in the field. These crucial factors largely determine the epidemiological and evolutionary success of plant viruses in natural settings. The nonfeeding modes of transmission have been explored in a few selective monopartite begomoviruses such as TYLCV, tomato yellow leaf curl Sardinia virus (TYLCSV), and tomato yellow leaf curl China virus (TYLCCNV) (Bosco et al. 2004; Czosnek et al. 2002; Ghanim et al. 1998; Wang et al. 2010). The frequency, feasibility, and epidemiological significance of these modes appear to vary between different studies involving similar monopartite viruses and the same vector, B. tabaci. However, a number of these attributes of nonfeeding transmission of bipartite begomoviruses and their virus replication in whiteflies remain to be studied.

A bipartite begomovirus, cucurbit leaf crumple virus ( $\mathrm{CuLCrV})$, either independently or in mixed infections with squash vein yellowing virus (SqVYV) and cucurbit yellow stunting disorder virus (CYSDV), causes a substantial economic loss to cucurbit production in the southeastern United States (Adkins et al. 2011). $\mathrm{CuLCrV}$ was first reported in the western United States (Arizona, Texas, and California) and northern Mexico (Brown and Czosnek 2002; Brown et al. 2000, 2002; Kuo et al. 2007). In the southeastern United States, CuLCrV was first reported in squash (Cucurbita pepo L.) fields in north-central and northeast Florida in 2006 (Adkins et al. 2009; Akad et al. 2008). The symptoms of CuLCrV include leaf curling and crumpling, chlorotic leaf spots, interveinal yellowing, plant stunting, and growth distortion. The tremendous population increase of $\mathrm{B}$. tabaci in Florida and Georgia in last 2 years complemented with $\mathrm{CuLCrV}$ incidence have caused extensive 
yield losses (Dawson 2016; Martini et al. 2016; McAvoy 2017). CuLCrV has two circular single-stranded DNA genome segments: DNA A (2,632 nucleotides) and DNA B (2,600 nucleotides). DNA $\mathrm{A}$ of $\mathrm{CuLCrV}$, being the most important genome component, which is homologous to monopartite begomoviruses, encodes proteins required for replication, regulation of gene expression, host defense resistance, encapsidation, and insect transmission (Briddon et al. 2010; Hagen et al. 2008). In contrast, DNA B encodes two proteins with functions in intra- and intercellular movement in host plants.

$\mathrm{CuLCrV}$ interactions with its vector remain unexplored. In this study, we investigated whether (i) CuLCrV DNA A is horizontally (transovarial) and vertically (mating) transmitted in B. tabaci, (ii) CuLCrV DNA A accumulation levels vary between feeding and nonfeeding modes of transmission using real time-PCR, and (iii) $\mathrm{CuLCrV}$ propagates in $B$. tabaci over three time points throughout adulthood.

\section{MATERIALS AND METHODS}

Host plants and CuLCrV inoculation. Squash (cultivar Goldstar) plants were grown in the greenhouse in whitefly-proof cages ( 47.5 by 47.5 by $93 \mathrm{~cm}$, length by width by height) at $25^{\circ} \mathrm{C}$ and $60 \%$ relative humidity $(\mathrm{RH})$, with a photoperiod of $16 \mathrm{~h}$ of light and $8 \mathrm{~h}$ of darkness. Three-week-old plants grown in MiracleGro compost were inoculated with CuLCrV using viruliferous $B$. tabaci. The whiteflies B. tabaci (Middle East-Asia Minor 1 [MEAM1], formerly the biotype B) were first collected in Tifton, GA and reared on cotton plants maintained in a different greenhouse. The viruliferous whiteflies were obtained by allowing newly emerged adults of B. tabaci to feed on CuLCrV-infected squash for $48 \mathrm{~h}$ in whitefly-proof cages. Fifteen whitefly-infested squash plants displaying $\mathrm{CuLCrV}$-like symptoms were obtained from a research plot in Tifton, GA, and infection status was confirmed by PCR using the conditions specified below. The first batch of greenhouseraised, $\mathrm{CuLCrV}$-infected squash plants was obtained from the fieldcollected plants through viruliferous whiteflies. The $\mathrm{CuLCrV}$ infection status of squash plants and viruliferous whiteflies was confirmed using PCR primers 3FAC3 (5'-TTTATATCATGA TTTTCGAGTACA-3') and 5RAC1 (5'-AAAATGAAAGCC TAAGAGAGTGGA-3') targeting the 525-bp amplicon of $A C 3$, $A C 2$, and $A C 1$ genes of the $\mathrm{CuLCrV}$ A component. The PCR involved initial DNA denaturation at $94^{\circ} \mathrm{C}$ for $5 \mathrm{~min}$; followed by 35 cycles of $94^{\circ} \mathrm{C}$ for $1 \mathrm{~min}, 54^{\circ} \mathrm{C}$ for $2 \mathrm{~min}$, and $72^{\circ} \mathrm{C}$ for $50 \mathrm{~s}$; and a final extension of $72^{\circ} \mathrm{C}$ for $10 \mathrm{~min}$. The PCR products were tested using gel electrophoresis with $2 \%$ agarose. The presence of other whitefly-transmitted viruses (CYSDV and SqVYV) was ruled out by testing recipient squash plants using reverse-transcription PCR (RT-PCR) following the conditions specified by Gadhave et al. (2018) and Adkins et al. (2007), respectively.

Transovarial transmission of CuLCrV. PCR detection of $\mathrm{CuLCrV}$ in whiteflies. Approximately 50 female B. tabaci whiteflies, after acquisition access to $\mathrm{CuLCrV}$ for $48 \mathrm{~h}$, were released onto cotton (nonhost) plants for oviposition over 1 week and then removed. The original egg-laying $B$. tabaci females were removed after 1 week, and the development of laid eggs was monitored throughout the life cycle. Cotton plants were grown in whiteflyproof cages ( 47.5 by 47.5 by $93 \mathrm{~cm}$, length by width by height) at $25^{\circ} \mathrm{C}$ and $60 \% \mathrm{RH}$, with a photoperiod of $16 \mathrm{~h}$ of light and $8 \mathrm{~h}$ of darkness. The acquisition of $\mathrm{CuLCrV}$ was confirmed in 10 individual whiteflies by PCR after removal from cotton plants. Fifty fourth-instar nymphs were removed randomly from the leaf surface using a heat-sterilized toothpick $\left(121^{\circ} \mathrm{C}\right.$ for $\left.15 \mathrm{~min}\right)$ and individually collected into sterile 1.5-ml Eppendorf tubes (Eppendorf, Hauppauge, NY, U.S.A.). Upon adult emergence, 50 B. tabaci adults from the same cotton plants were collected randomly using an aspirator. Individual nymphs and adults were surface sterilized with a series of five $500-\mu l$ washes in the following order: $70 \%$ ethanol, sterile nuclease-free water, $1 \%$ sodium hypochlorite, sterile nuclease-free water, and sterile nuclease-free water. The final rinsates were tested with PCR using the conditions specified above to confirm no external contamination with $\mathrm{CuLCrV}$ via honeydew. The total DNA from nymph and adult samples was extracted individually using BioRad Instagene Matrix (Bio-Rad Laboratories, Inc.) following the manufacturer's protocol. The DNA extracts were subjected to PCR following the conditions specified above to determine whether CuLCrV DNA A was transmitted from mother to offspring. The experiment was repeated once more. In total, 100 fourth-instar nymphs and adults were evaluated for transovarial transmission.

Infectivity to plants. One hundred individual whiteflies that completed their life cycle on cotton plants in the transovarial experiment were clip-caged to 3 -week-old noninfected squash. All whiteflies were removed post $48 \mathrm{~h}$ inoculation access period (IAP), and plants were sprayed with Admire Pro insecticide (Bayer Crop Science LP) to kill any remaining whiteflies. Squash plants were kept in whitefly-proof cages for 4 weeks to observe for $\mathrm{CuLCrV}$ symptom development. After 4 weeks, $100 \mathrm{mg}$ of leaf tissue was sampled and total DNA was extracted using the GeneJET Plant Genomic DNA Purification Mini Kit (Thermo Fisher Scientific Inc.) following the manufacturer's instructions. With two experimental repeats, the infection status of 20 squash plants in total was tested with PCR, as described above.

Mating transmission of CuLCrV. PCR detection of $\mathrm{CuLCrV}$ in whiteflies. Individual viruliferous male or female B. tabaci whiteflies were clip-caged with their nonviruliferous counterparts on cotton for 2 days to allow for mating. The viruliferous whiteflies were obtained by allowing newly emerged whiteflies from cotton to feed on $\mathrm{CuLCrV}$-infected squash plants for $48 \mathrm{~h}$. After $48 \mathrm{~h}$ of mating, both male and female insects from each clip cage were collected individually and surface sterilized with a series of five $500-\mu l$ washes as described above, and the final rinsates were tested for successful surface sterilization through PCR. B. tabaci DNA was extracted using BioRad Instagene Matrix. The DNA from both viruliferous males or females and their mating nonviruliferous counterparts were tested using PCR as described above. These confirmed whether supposedly viruliferous males or females were indeed viruliferous, and whether the viral DNA was transmitted to originally nonviruliferous counterparts through mating. Thirty pairs of each positive male/negative female and positive female/negative male combination were tested in three experimental repeats. Of the 30 , only pairs in which CuLCrV DNA A was detected in a supposedly viruliferous male or female partner through PCR amplification were considered replicates.

Infectivity to plants. In all, 150 viruliferous male or female B. tabaci whiteflies were clip-caged with 150 of their nonviruliferous counterparts on cotton for $48 \mathrm{~h}$ to allow for mating to occur. After 2 days, 100 of the initially nonviruliferous whiteflies, after microscopic confirmation of sexes, were clip-caged for a 48-h IAP onto a 3-week-old noninfected squash plant in whitefly-proof cages. Post 48-h IAP, whiteflies were removed and plants were sprayed with Admire Pro insecticide to ensure no subsequent whitefly survival and feeding. The infection status of these plants 4 weeks past inoculation was tested using PCR as described above. The experiment was conducted twice with 10 plants in total for each positive male/negative female and positive female/negative male combination ( $n=10$ insects/combination).

CuLCrV accumulation using real-time PCR. CuLCrV accumulation in (i) squash infected with $\mathrm{CuLCrV}$ and (ii) whiteflies that acquired virus through feeding on $\mathrm{CuLCrV}$-infected squash plants and through nonfeeding modes (i.e., transovarial and mating) was quantified using real time-PCR under the conditions specified below. The total DNA from $100 \mathrm{mg}$ of young infected squash leaf tissue $(n=10)$ in the apex region was extracted using the GeneJET Plant Genomic DNA Purification Mini Kit as described above. The total DNA from individual whiteflies $(n=10)$ was extracted using the BioRad Instagene Matrix as described above. Whiteflies were 
allowed to acquire $\mathrm{CuLCrV}$ DNA through at least $48 \mathrm{~h}$ of feeding on CuLCrV-infected plants. The CuLCrV DNA from seven transovarially transmitted samples totaling four nymphs and three adults, and from two mating-transmitted samples containing a viruliferous donor male and viruliferous recipient female, were used for a comparative RT-PCR assay.

Quantitative PCR (qPCR) was carried out using $2 \times$ GoTaq qPCR Master Mix (Promega Corp., Madison, WI, U.S.A.) in Eppendorf MasterCycler RealPlex (Eppendorf, Hauppauge, NY, U.S.A.). Primers (forward 5'-CCTCAAAGGTTTCCCGCTCT-3' and reverse 5'-CCGATAGATCCTGGGCTTCC-3') which amplify a 110-bp region of the coat protein $(\mathrm{CP})$ gene of $\mathrm{CuLCrV}$ were used in the qPCR. GoTaq qPCR Master Mix was combined with forward and reverse primers (final concentration of $5 \mathrm{pmol}$ ), DNA (10 ng for plants or $20 \mathrm{ng}$ for insects), and nuclease-free water to make a final volume of $25 \mu \mathrm{l}$. Cycling parameters were as follows: $95^{\circ} \mathrm{C}$ for $2 \mathrm{~min}$, followed by 40 cycles of $95^{\circ} \mathrm{C}$ for $15 \mathrm{~s} \mathrm{~min}, 63^{\circ} \mathrm{C}$ for $15 \mathrm{~s}$, and $72^{\circ} \mathrm{C}$ for $20 \mathrm{~s}$. Upon completion of the run, melting curve analysis was performed to confirm the specificity of the primer pairs. Each sample was tested in duplicate, and absolute copies in the samples were quantified using a standard curve developed using the protocol described earlier by Legarrea et al. (2015). Briefly, plasmids carrying a PCR amplicon (110 bp) were generated. Numbers of copies were measured using the formula: number of copies $=$ (amount in nanograms $\left.\times 6.022 \times 10^{23}\right) /($ length of vector in base pairs $\times 1 \times 10^{9} \times 650$ ). For each qPCR run, duplicates of eight-step 10 -fold serial dilutions of plasmids (standard) were loaded in the plate to build the appropriate standard curve.

Virus propagation. Newly emerged whiteflies from cotton were transferred to $\mathrm{CuLCrV}$-infected squash to acquire virus for 48 h. Whiteflies were later moved to 3-week-old cotton plants and $\mathrm{CuLCrV}$ accumulation in whiteflies was determined at three different time points: 2, 8, and 14 days post-acquisition (DPA). At each time point, total DNA from seven individual whiteflies was extracted using BioRad Instagene Matrix (Bio-Rad Laboratories,
Inc.) and subjected to real-time PCR as specified above. The experiment was repeated once more $(n=14)$.

Statistical analyses. Data analyses were performed in R, version 3.4.2 (The $\mathrm{R}$ Foundation for Statistical Computing). Differences in $\mathrm{CuLCrV}$ accumulation in individual whiteflies between feeding, vertical, and horizontal modes of transmission were analyzed using a Kruskal-Wallis test with the mean separation using a Dunn test ('kruskal.test' and 'dunn.test' functions in R). CuLCrV accumulation at three time points (2, 8, and 14 days after the acquisition access period) was analyzed using one-way analysis of variance. The means separation was performed using Tukey's honestly significant difference posthoc test.

\section{RESULTS}

Transovarial transmissions of CuLCrV. PCR analysis revealed that 4 of the 102 B. tabaci fourth-instar nymphs (3.93\%) were infected with $\mathrm{CuLCrV}$ (Table 1). Furthermore, 3 of the 97 newly emerged adults (3.09\%) tested positive for CuLCrV. All the seven samples positive for $\mathrm{CuLCrV}$ were partially sequenced using the 5RAC1 primer pair and submitted to NCBI GenBank (accession numbers MG018752 to MG018758). None of the 20 plants tested 30 days postinoculation (following transovarial acquisition) contained detectable CuLCrV DNA A or showed typical disease symptoms (Table 1).

Mating transmission of CuLCrV. PCR analysis confirmed that the 25 males from the 30 viruliferous male/nonviruliferous female pair combinations were positive for CuLCrV DNA (Table 1). Similarly, 26 of the 30 viruliferous female/nonviruliferous male pair combinations were positive for CuLCrV DNA A. Hence, the data from these replicates alone were considered for the horizontal $\mathrm{CuLCrV}$ transmission analyses. Only 1 of the 25 nonviruliferous females tested positive for CuLCrV DNA following mating with viruliferous males. However, no nonviruliferous males tested positive for $\mathrm{CuLCrV}$ following mating with viruliferous females.

TABLE 1. Transovarial transmission of cucurbit leaf crumple virus (CuLCrV) from viruliferous whiteflies to progeny and mating transmission of CuLCrV from viruliferous males to nonviruliferous females and vice versa, with corresponding plant infection data ${ }^{\mathrm{a}}$

\begin{tabular}{|c|c|c|c|c|c|c|c|c|c|}
\hline \multirow[b]{2}{*}{ Transmission, modes, tests } & \multicolumn{3}{|c|}{ Whiteflies (\%) } & \multicolumn{3}{|c|}{ Plants $(\%)$} & \multirow[b]{2}{*}{$\chi^{2}$} & \multirow[b]{2}{*}{$P$} & \multirow[b]{2}{*}{$P$-adj } \\
\hline & $N$ & + & - & $N$ & + & - & & & \\
\hline \multicolumn{10}{|l|}{ Transovarial } \\
\hline \multicolumn{10}{|l|}{ Generation 1} \\
\hline Adults & 97 & $3(3.09)$ & $94(96.9)$ & 9 & $0(0)$ & $9(100)$ & $\ldots$ & $\ldots$ & $\ldots$ \\
\hline \multicolumn{10}{|l|}{ Generation 2} \\
\hline Nymphs & 50 & $0(0)$ & $50(100)$ & 10 & $0(0)$ & $10(100)$ & $\ldots$ & $\ldots$ & $\ldots$ \\
\hline V-F to NV-M & 26 & $0(0)$ & $26(100)$ & 9 & $0(0)$ & $9(100)$ & $\ldots$ & $\ldots$ & $\ldots$ \\
\hline \multicolumn{10}{|l|}{ Feeding and nonfeeding ${ }^{\mathrm{d}}$} \\
\hline $\begin{array}{l}\text { Kruskal-Wallis test } \\
\text { Dunn test }\end{array}$ & $\ldots$ & $\cdots$ & $\ldots$ & $\ldots$ & $\cdots$ & $\ldots$ & 25.53 & $<0.001$ & $\cdots$ \\
\hline Fd-Tr (nymphs) & $\ldots$ & $\ldots$ & $\ldots$ & $\ldots$ & $\ldots$ & $\ldots$ & $\ldots$ & $\ldots$ & $<0.001$ \\
\hline Fd-Tr (adults) & $\ldots$ & $\ldots$ & $\ldots$ & $\ldots$ & $\ldots$ & $\ldots$ & $\ldots$ & $\ldots$ & $<0.001$ \\
\hline Time point $1-2$ & $\ldots$ & $\ldots$ & $\ldots$ & $\ldots$ & $\ldots$ & $\ldots$ & $\ldots$ & $\ldots$ & $<0.001$ \\
\hline Time point 1-3 & $\ldots$ & $\ldots$ & $\ldots$ & $\ldots$ & $\ldots$ & $\ldots$ & $\ldots$ & $\ldots$ & $<0.001$ \\
\hline Time point $2-3$ & $\ldots$ & $\ldots$ & $\ldots$ & $\ldots$ & $\ldots$ & $\ldots$ & $\ldots$ & $\ldots$ & 0.001 \\
\hline
\end{tabular}


$\mathrm{CuLCrV}$ DNA A from both the donor male and recipient female that had acquired the virus through mating was partially sequenced and submitted to the GenBank (accession numbers MG018759 to MG018760). Both of these sequences, when aligned pairwise, showed $100 \%$ homology. Consistent with the results from transovarial transmission, none of the 20 plants tested 30 days postinoculation (following acquisition via mating) contained detectable CuLCrV DNA A or showed typical disease symptoms (Table 1).

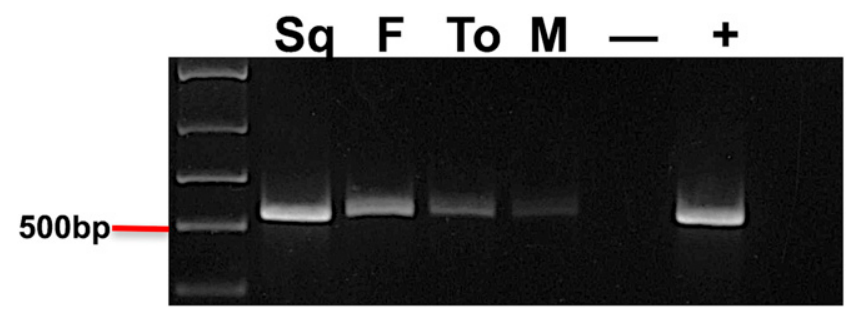

Fig. 1. PCR-based detection of cucurbit leaf crumple virus (CuLCrV) DNA A in representative virus-infected squash $(\mathrm{Sq})$, and individual whiteflies that acquired $\mathrm{CuLCrV}$ through feeding $(\mathrm{F})$, transovarial (To), and mating $(\mathrm{M})$ modes. 3FAC3 and 5RAC1 primers targeting the 525-bp amplicon of $A C 1$, $A C 2$, and $A C 3$ genes. Negative (-) and positive (+) controls are indicated.
Quantification of CuLCrV DNA A. RT-PCR showed that individual whiteflies accumulated the highest amounts of $\mathrm{CuLCrV}$ DNA A via feeding, followed by nonfeeding modes of transmission (Figs. 1 and 2). The pairwise comparisons using Dunn's test showed that the $\mathrm{CuLCrV}$ accumulation via feeding was significantly higher than transovarial (both nymph and adult) and mating transmission modes (Table 1). Although CuLCrV accumulation was lowest via mating transmission, it was not significantly different than transovarial mode.

Virus propagation. RT-PCR showed significant differences in $\mathrm{CuLCrV}$ copy numbers between all three time points (Table 1 ). The mean copy number of $\mathrm{CuLCrV}$ in $B$. tabaci was significantly higher at the first time point (2 DPA) and decreased subsequently at the second (8 DPA) and third (14 DPA) time points (Fig. 3).

\section{DISCUSSION}

We report low-frequency vertical (transovarial) and horizontal (mating) transmission of $\mathrm{CuLCrV}$ by $B$. tabaci MEAM1. The magnitude and frequency of transovarial transmission of $\mathrm{CuLCrV}$ (as determined by DNA A detection) was comparatively similar to TYLCV and other monopartite begomoviruses. For instance, TYLCV was the first begomovirus reported to be transmitted transovarially to the succeeding B. tabaci (biotypes B and Q) generation in both nymph and adult stages (Ghanim et al. 1998;

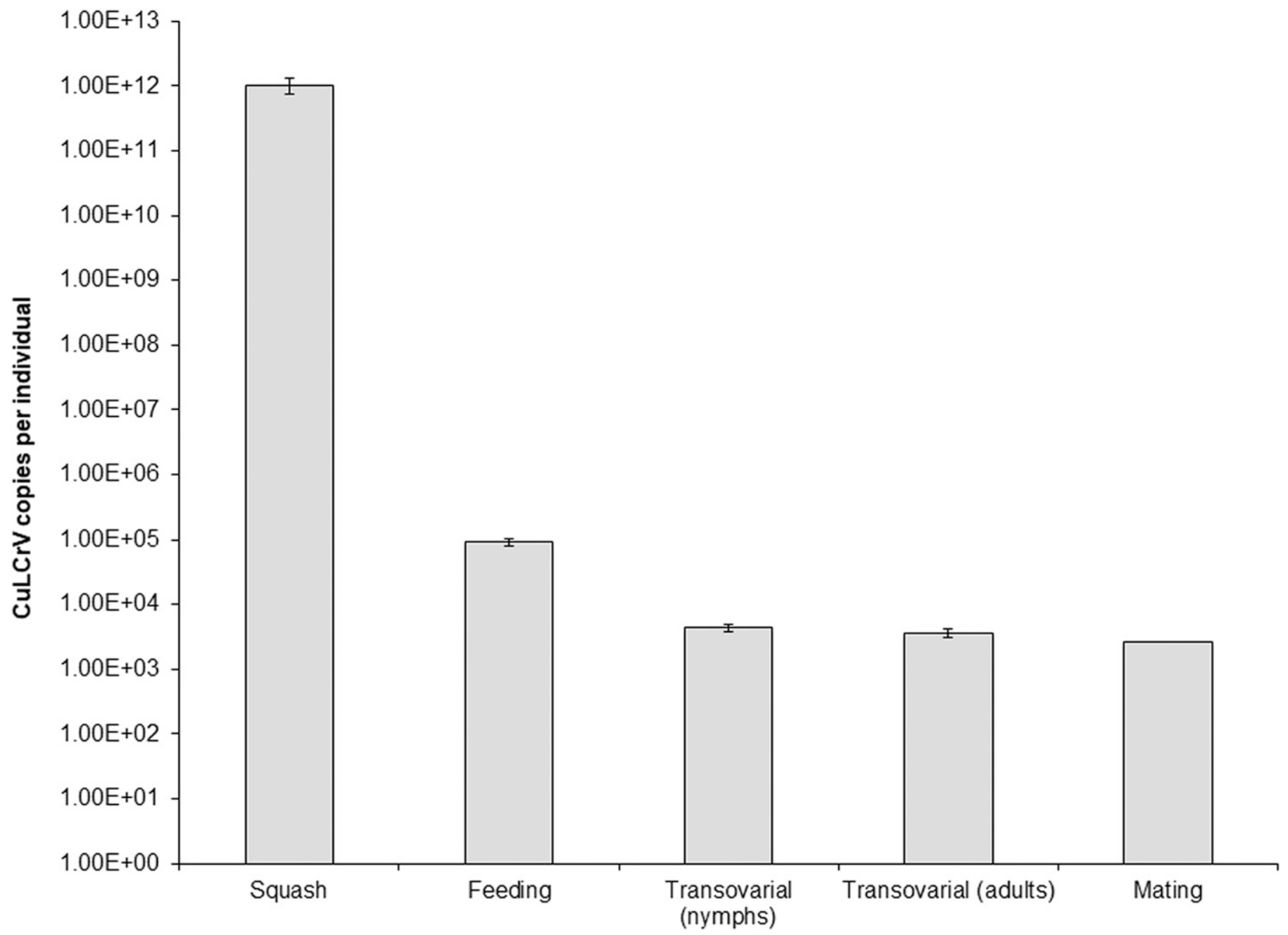

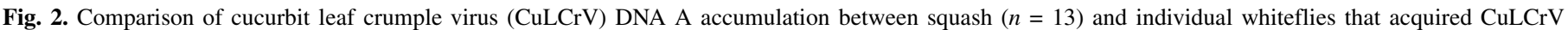

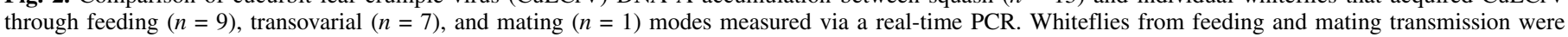

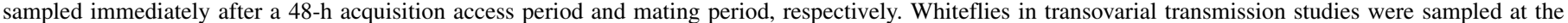
fourth-instar nymphal stage and adult stage immediately after eclosion. 
Wang et al. 2010). However, extensive variation in the frequencies was observed between two previous studies. The percent transovarial transmission was reported as high as $36.8 \%$ for crawlers and $56.8 \%$ for adults (Ghanim et al. 1998) and as low as $2.5 \%$ for pupa (Wang et al. 2010). Furthermore, Bosco et al. (2004) and Wang et al. (2010) reported the absence of transovarial transmission of TYLCV by $B$. tabaci in adult stages. The disparity in transovarial transmission of TYLCV between different studies was assumed to be due to inherent differences in the virus strains and inbred whitefly colonies used in these different studies. The transovarial transmission frequencies for two other closely related monopartite begomoviruses-TYLCSV (29\% nymphs) (Bosco et al. 2004) and TYLCCNV (8\% pupae) (Wang et al. 2010)—were reported to be relatively higher than what is observed in our current study with $\mathrm{CuLCrV}$. However, transovarial transmission frequency of $\mathrm{CuLCrV}$ observed in this study in adult whiteflies was slightly higher (3.09\%) than the one observed for TYLCSV (2\%) (Bosco et al. 2004).

Only 1 of 25 viruliferous males was found to transmit $\mathrm{CuLCrV}$ to a nonviruliferous female through mating in this study. This is in agreement with a previous study, in which the percent horizontal transmission of TYLCV and TYLCCNV was reported below 5\% (Wang et al. 2010). Two bipartite begomoviruses infecting cucurbits, squash leaf curl virus (SLCV) and watermelon chlorotic stunt virus (WmCSV), were also reported to be transmitted horizontally (Ghanim et al. 2007). In an earlier study, Ghanim and Czosnek (2000) reported higher frequencies of horizontal transmission: $56.6 \%$ of the nonviruliferous females and $27.8 \%$ of the nonviruliferous males were reported to acquire TYLCV DNA through mating. Similarly, WmCSV DNA was detected in $14.2 \%$ of nonviruliferous females and $50 \%$ of nonviruliferous males, whereas SLCV DNA was detected in $22.2 \%$ of nonviruliferous females and $13.6 \%$ of nonviruliferous males after mating. Thus, the frequency values for all three begomoviruses suggest better horizontal transmission of each of these viruses than CuLCrV. Unlike CuLCrV, viruliferous females were reported to transmit all of these begomoviruses to nonviruliferous males (Ghanim and Czosnek 2000; Ghanim et al. 2007; Wang et al. 2010).

The present study showed similarity with an array of studies on TYLCV, in which the recipient $B$. tabaci adult progeny that acquired $\mathrm{CuLCrV}$ via transovarial transmission was unable to transmit CuLCrV to noninfected squash plants (Bosco et al. 2004; Cohen and Nitzany 1966; Ioannou 1985; Wang et al. 2010). This has also been observed with a variety of other begomoviruses, including tomato leaf curl virus, SLCV, tomato leaf curl Sinaloa virus, TYLCSV, and TYLCCV (Bosco et al. 2004; Butter and Rataul 1977; Cohen et al. 1983; Hidayat et al. 2008; Idris and Brown 1998; Wang et al. 2010). The lack of plant infection by whiteflies following horizontal transmission in whiteflies appears to be a common feature widely shared among begomoviruses. However, Ghanim and Czosnek (2000) reported that nonviruliferous female and male recipients of TYLCV infected 34.5 and $23.8 \%$ of tomato plants, respectively. A more recent study by Wei et al. (2017) showed that the developmental stage of the whitefly ovary and the

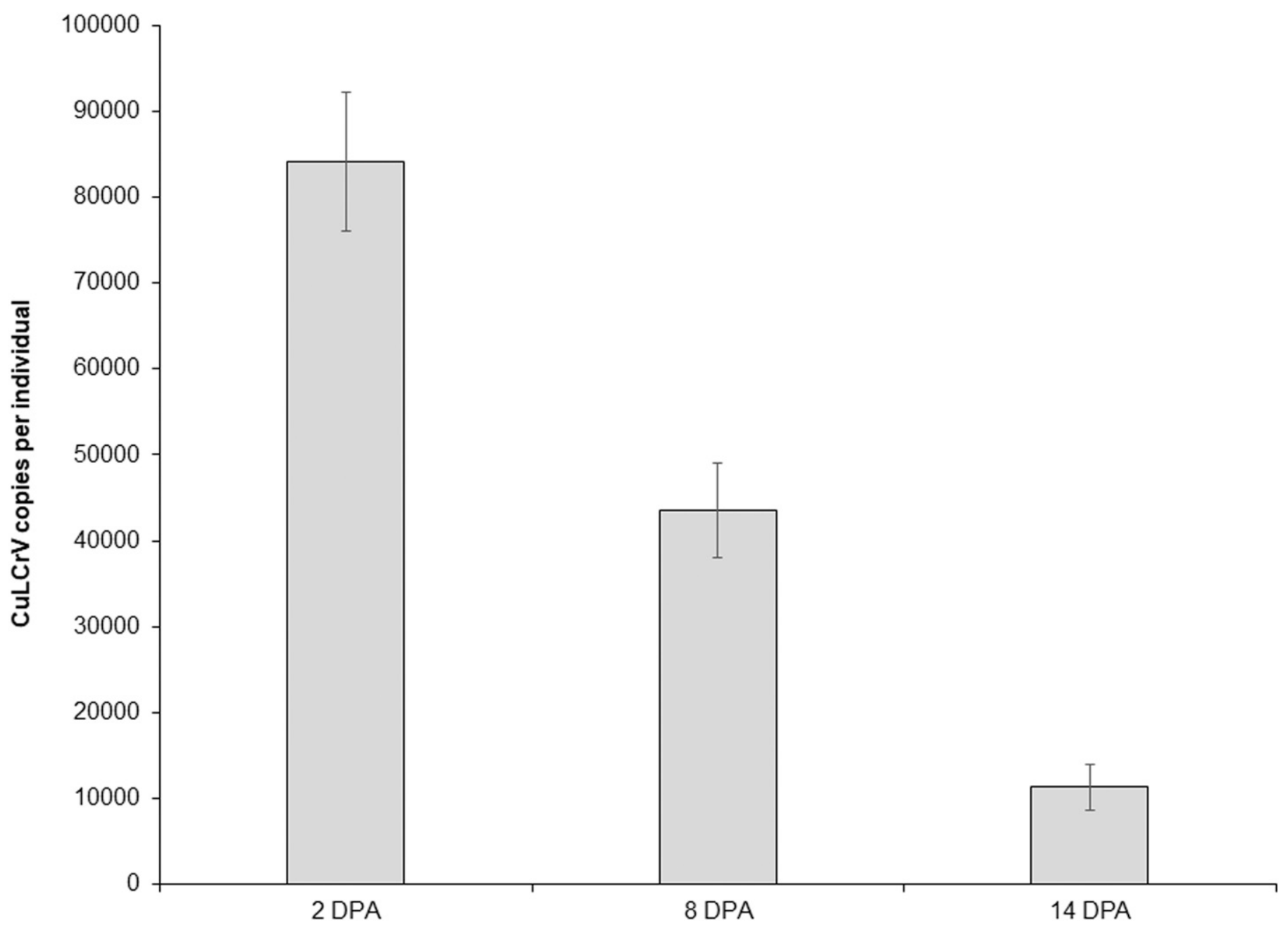

Fig. 3. Comparison of cucurbit leaf crumple virus $(\mathrm{CuLCrV})$ DNA A accumulation in individual whiteflies at 2, 8 , and 14 days post-acquisition $(\mathrm{DPA})(n=14)$ measured via real-time PCR. The decline in CuLCrV copy number over time was statistically significant. 
age of the viruliferous whiteflies determine the transovarial transmission efficiency of TYLCV. For instance, 1 day after emergence, adult whiteflies were able to transmit TYLCV to the eggs and nymphs of their progenies in a low frequency, with no TYLCV DNA found in the adult progenies. In contrast, 11 days after emergence, adult whiteflies were able to transmit TYLCV to all developmental stages of their progeny, with adults transmitting the virus to test plants. Similarly, it is plausible that the developmental stage of the whitefly ovary and whitefly age may have influenced the transovarial transmission of $\mathrm{CuLCrV}$ and the resulting plant infectivity. Furthermore, it is also plausible that only CuLCrV DNA A (either a part of DNA A including AC3, AC2 and $A C 1$ genes or the entire DNA A) was transmitted to recipient whiteflies through transovarial and mating transmissions. Bipartite begomoviruses require the assembly of both $\mathrm{CuLCrV}$ DNA components A and B into virions for successful infection in plants (Sanderfoot and Lazarowitz 1996). The failure of virion formation as a result of lacking either the complete A component or entire B component may have prevented plant infection with $\mathrm{CuLCrV}$ by whiteflies following transovarial and mating transmissions. We did not test whiteflies to confirm the presence of $\mathrm{CuLCrV}$ part $\mathrm{B}$ in this study.

Vector biotype, sex, and genetic makeup have been reported to determine the extent and outcome of virus transmission via nonfeeding modes (Ghanim and Czosnek 2000; Ning et al. 2015). Horizontal transmission was documented at low levels and only from viruliferous male to recipient female whitefly. Viruliferous females were unable to transmit $\mathrm{CuLCrV}$ to recipient nonviruliferous males through mating. $\mathrm{CuLCrV}$ mating transmission may have occurred through deposition of sperm cell or seminal fluid containing CuLCrV DNA directly into haemolymph or spermatheca of recipient females during copulation, as suggested for TYLCV (Czosnek 2007). Although the exact mechanisms by which begomoviruses enter the reproductive system of insects are unknown, it has recently been demonstrated that a highly specific interaction between TYLCV CP and whitefly vitellogenin is required for the TYLCV entry into the reproductive organ of B. tabaci (Wei et al. 2017). These appear to be dependent on the developmental stage of the whitefly ovary and whitefly adult age.

As in TYLCV, a significant decline in viral DNA levels at different time points throughout adulthood was also observed in CuLCrV (Becker et al. 2016; Sánchez-Campos et al. 2016). Begomoviruses often have an intricate association with their vectors; however, most are believed not to propagate within vectors. For instance, two recent studies (Becker et al. 2016; SánchezCampos et al. 2016) demonstrated that TYLCV DNA levels in individual whiteflies did not increase at different time points following virus acquisition. Hence, no virus propagation was observed in whiteflies, contrasting with an earlier study on TYLCV (Pakkianathan et al. 2015) that reported otherwise.

The results of our present study demonstrate that vertical and horizontal transmission of CuLCrV is very low and no plant infection was detected. Taken together, our results suggest that these modes of virus transmission are unlikely to be of epidemiological significance. Furthermore, due to the absence of plant infection, vertical and horizontal transmission in whiteflies may not serve as an alternate pathway of maintaining $\mathrm{CuLCrV}$ inoculum continuously between cropping seasons. With mild winters being the norm in the southeastern states such as Florida and Georgia, CuLCrV is likely to have more presence because a number of alternate hosts serve as $\mathrm{CuLCrV}$ reservoirs throughout the year. A wide range of host plants (as opposed to the maintenance of $\mathrm{CuLCrV}$ inoculum in the vector) through seasons could play a more crucial role in CuLCrV epidemiology (Moury et al. 2017), in that having multiple hosts increases the chances of virus spread through increased availability of inoculum for primary spread of virus and increased acquisition by vectors. The availability of abundant alternate crop hosts such as cucumber, muskmelon, pumpkin, watermelon, and green bean in a short growing season combined with huge whitefly populations appeared to have resulted in the outbreak of $\mathrm{CuLCrV}$ as reported in recent years in the southeastern United States (Dawson 2016; Martini et al. 2016).

Concluding remarks. Our present study was consistent with an array of previous studies, in that low-frequency horizontal and vertical transmission of begomoviruses, together with no virus propagation in whiteflies, appear to be widely shared common features. Furthermore, with a few exceptions, it is also evident that recipient whiteflies, acquiring virus through the nonfeeding transmission modes, fail to transmit virus to noninfected plants. Thus, it is plausible that $\mathrm{CuLCrV}$ presence in whiteflies in itself may not significantly lead to its epidemics every year.

\section{ACKNOWLEDGMENTS}

We thank W. Marchant for her help with RT-PCR analysis; and S. McKeown, S. Diffie, and S. Thompson for their help with greenhouse work.

\section{LITERATURE CITED}

Adkins, S., Polston, J. E., and Turechek, W. W. 2009. Cucurbit leaf crumple virus identified in common bean in Florida. Plant Dis. 93:320.

Adkins, S., Webb, S. E., Achor, D., Roberts, P. D., and Baker, C. A. 2007. Identification and characterization of novel whitely-transmitted member of the family Potyviridae isolated from cucurbits in Florida. Phytopathology 97:145-154.

Adkins, S., Webster, C. G., Kousik, C. S., Webb, S. E., Roberts, P. D., Stansly, P. A., and Turechek, W. W. 2011. Ecology and management of whitefly-transmitted viruses of vegetable crops in Florida. Virus Res. 159: 110-114.

Akad, F. W. S., Nyoike, T. W., Liburd, O. E., Turechek, W., Adkins, S., and Polston, J. E. 2008. Detection of Cucurbit leaf crumple virus in Florida cucurbits. Plant Dis. 92:648.

Becker, N., Rimbaud, L., Chiroleu, F., Reynaud, B., Thébaud, G., and Lett, J.-M. 2016. Rapid accumulation and low degradation: Key parameters of Tomato yellow leaf curl virus persistence in its insect vector Bemisia tabaci. Sci. Rep. 5:17696.

Bosco, D., Mason, G., and Accotto, G. P. 2004. TYLCSV DNA, but not infectivity, can be transovarially inherited by the progeny of the whitefly vector Bemisia tabaci (Gennadius). Virology 323:276-283.

Briddon, R. W., Patil, B. L., Bagewadi, B., Nawaz-ul-Rehman, M. S., and Fauquet, C. M. 2010. Distinct evolutionary histories of the DNA-A and DNA-B components of bipartite begomoviruses. BMC Evol. Biol. 10: 97.

Brown, J. K., and Czosnek, H. 2002. Whitefly transmission of plant viruses. Adv. Bot. Res. 36:65-100.

Brown, J. K., Fauquet, C. M., Briddon, R. W., Zerbini, M., Moriones, E., and Navas-Castillo, J. 2012. Family Geminiviridae. Pages 351-373 in: Virus Taxonomy. Ninth Report of the International Committee on Taxonomy of Viruses. A. M. Q. King, M. J. Adams, E. B. Carstens, and E. J. Lefkowitz, eds. Elsevier Academic Press, London, U.K.

Brown, J. K., Idris, A. M., Alteri, C., and Stenger, D. C. 2002. Emergence of a new cucurbit-infecting begomovirus species capable of forming viable reassortants with related viruses in the Squash leaf curl virus cluster. Phytopathology 92:734-742.

Brown, J. K., Idris, A. M., Olsen, M. W., Miller, M. E., Isakeit, T., and Anciso, J. 2000. Cucurbit leaf curl virus, a new whitefly transmitted geminivirus in Arizona, Texas, and Mexico. Plant Dis. 84:809.

Butter, N. S., and Rataul, H. S. 1977. The virus-vector relationship of the Tomato leafcurl virus (TLCV) and its vector, Bemisia tabaci Gennadius (Hemiptera: Aleyrodidae). Phytoparasitica 5:173-186.

Cohen, S., Duffus, J. E., Larsen, R. C., Liu, H. Y., and Flock, R. A. 1983. Purification, serology, and vector relationships of Squash leaf curl virus, a whitefly-transmitted geminivirus. Phytopathology 73:1669-1673.

Cohen, S., and Nitzany, F. E. 1966. Transmission and host range of the Tomato yellow leaf curl virus. Phytopathology 56:1127-1131.

Czosnek, H. 2007. Interactions of Tomato yellow leaf curl virus with its whitefly vector. Pages 157-170 in: Tomato Yellow Leaf Curl Virus Disease. H. Czosnek, ed. Springer Netherlands, Dordrecht, The Netherlands.

Czosnek, H., Ghanim, M., and Ghanim, M. 2002. The circulative pathway of begomoviruses in the whitefly vector Bemisia tabaci-Insights from studies with Tomato yellow leaf curl virus. Ann. Appl. Biol. 140: 215-231. 
Dawson, K. 2016. Whitefly populations troubling Georgia vegetable growers. University of Georgia. https://vegetablegrowersnews.com/news/whiteflypopulations-troubling-georgia-vegetable-growers/

Gadhave, K. R., Dutta, B., Coolong, C., Sparks, A. N., Adkins, S., and Srinivasan, R. 2018. First Report of a Cucurbit yellow stunting disorder virus in cucurbits in Georgia, United States. Plant Health Prog. 19:9-10.

Ghanim, M., and Czosnek, H. 2000. Tomato yellow leaf curl geminivirus (TYLCV-Is) is transmitted among whiteflies (Bemisia tabaci) in a sexrelated manner. J. Virol. 74:4738-4745.

Ghanim, M., Morin, S., Zeidan, M., and Czosnek, H. 1998. Evidence for transovarial transmission of Tomato yellow leaf curl virus by its vector, the whitefly Bemisia tabaci. Virology 240:295-303.

Ghanim, M., Sobol, I., Ghanim, M., and Czosnek, H. 2007. Horizontal transmission of begomoviruses between Bemisia tabaci biotypes. Arthropod-Plant Interact. 1:195-204.

Hagen, C., Rojas, M. R., Kon, T., and Gilbertson, R. L. 2008. Recovery from Cucurbit leaf crumple virus (family Geminiviridae, genus Begomovirus) infection is an adaptive antiviral response associated with changes in viral small RNAs. Phytopathology 98:1029-1037.

Hidayat, S. H., Orawan, C., and Noor, A. 2008. Molecular identification and sequence analysis of Tobacco leaf curl begomovirus from Jember, East Java, Indonesia. Hayati J. Biosci. 15:13-17.

Hogenhout, S. A., El-Desouky, A., Whitfield, A. E., and Redinbaugh, M. G. 2008. Insect vector interactions with persistently transmitted viruses. Annu. Rev. Phytopathol. 46:327-359.

Idris, A. M., and Brown, J. K. 1998. Sinaloa tomato leaf curl geminivirus: Biological and molecular evidence for a new subgroup III virus. Phytopathology 88:648-657.

Ioannou, N. 1985. Yellow leaf curl and other virus diseases of tomato in Cyprus. Plant Pathol. 34:428-434.

Jia, D., Chen, Q., Mao, Q., Zhang, X., Wu, W., Chen, H., Yu, X., Wang, Z., and Wei, T. 2018. Vector mediated transmission of persistently transmitted plant viruses. Curr. Opin. Virol. 28:127-132.

Kuo, Y. W., Rojas, M. R., Gilbertson, R. L., and Wintermantel, W. M. 2007. First report of Cucurbit yellow stunting disorder virus in California and Arizona, in Association with Cucurbit leaf crumple virus and Squash leaf curl virus. Plant Dis. 91:330.
Legarrea, S., Barman, A., Marchant, W., Diffie, S., and Srinivasan, R. 2015. Temporal effects of a Begomovirus infection and host plant resistance on the preference and development of an insect vector, Bemisia tabaci, and implications for epidemics. PLoS One 10:e0142114.

Martini, X., Paret, M., and Freeman, J. 2016. Early outbreaks of sweetpotato whiteflies. Citrus Ind. November 2016:26-27. https://www.researchgate.net/ publication/310749519_Early_outbreaks_of_sweetpotato_whiteflies

McAvoy, G. 2017. Take caution to curb Cucurbit Leaf Crumple Virus. Growing Produce. https://www.growingproduce.com/crop-protection/disease-control/ take-caution-to-curb-cucurbit-leaf-crumple-virus/

Moury, B., Fabre, F., Hébrard, E., and Froissart, R. 2017. Determinants of host species range in plant viruses. J. Gen. Virol. 98:862-873.

Ning, W., Shi, X., Liu, B., Pan, H., Wei, W., Zeng, Y., Sun, X., Xie, W., Wang, S., and Wu, Q. 2015. Transmission of Tomato yellow leaf curl virus by Bemisia tabaci as affected by whitefly sex and biotype. Sci. Rep. 5:10744.

Pakkianathan, B. C., Kontsedalov, S., Lebedev, G., Mahadav, A., Zeidan, M., Czosnek, H., and Ghanim, M. 2015. Replication of Tomato yellow leaf curl virus in its whitefly vector, Bemisia tabaci. J. Virol. 89:9791-9803.

Roselló, S., Díez, M. J., and Nuez, F. 1996. Viral diseases causing the greatest economic losses to the tomato crop. I. The Tomato spotted wilt virus-A review. Sci. Hortic. (Amsterdam) 67:117-150.

Sánchez-Campos, S., Rodríguez-Negrete, E. A., Cruzado, L., Grande-Pérez, A., Bejarano, E. R., Navas-Castillo, J., and Moriones, E. 2016. Tomato yellow leaf curl virus: No evidence for replication in the insect vector Bemisia tabaci. Sci. Rep. 6:30942.

Sanderfoot, A. A., and Lazarowitz, S. G. 1996. Getting it together in plant virus movement: Cooperative interactions between bipartite geminivirus movement proteins. Trends Cell Biol. 6:353-358.

Wang, J., Zhao, H., Liu, J., Jiu, M., Qian, Y. J., and Liu, S. S. 2010. Low frequency of horizontal and vertical transmission of two begomoviruses through whiteflies exhibits little relevance to the vector infectivity. Ann. Appl. Biol. 157:125-133.

Wei, J., He, Y. Z., Guo, Q., Guo, T., Liu, Y. Q., Zhou, X. P., Liu, S. S., and Wang, X. W. 2017. Vector development and vitellogenin determine the transovarial transmission of begomoviruses. Proc. Natl. Acad. Sci. U.S.A. 114:6746-6751.

Whitfield, A. E., Falk, B. W., and Rotenberg, D. 2015. Insect vector-mediated transmission of plant viruses. Virology 479-480:278-289. 